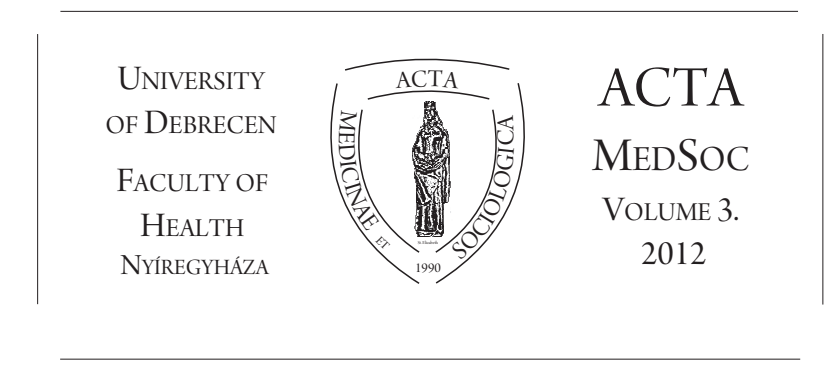

\title{
Szituáció- és érzelemfüggő eredménytorzítás egy iskolai integrációs program hatásvizsgálatában
}

\author{
Hüse Lajos \\ Debreceni Egyetem Egészségügyi Kar, Társadalomtudományi Tanszék \\ e-mail: Huse.lajos@foh.unideb.hu
}

\begin{abstract}
Situational and emotional outcome bias in an impact assessment of a school integration program.

The sociometric impact assessment accomplished in a support program of Roma children's integration in schools ('Dear school' program in Nyíregyháza) showed a contradictory picture of the experiences of participating professionals. The sociometric examination found a negative trend, whereas the personal experiences of professionals are clearly positive. The professionals' involuntary outcome bias released the dissonance of observance, attributing positive reasons with creative interpretation of the negative test results. After the impact assessment I performed a two-step experiment in order to examine how group processes can clearly suggest a negative sociogram pair of pre-evaluation of the induced orientation of emotions, depending on the situation or expectations perceiving the existence of external pressure.
\end{abstract}

Keywords: school integration, impact assessment, sociometric measure, outcome bias

DOI: $10.19055 / \mathrm{ams} .2012 .3 / 4-5 / 2$

„Savanyú a szólô”, állítja Aesopus meséjének rókája, miután hiába nyújtózkodik a lugas csábítóan illatozó fürtjei után, majd dühösen, de büszkeségét megớrizve távo- 
zik a helyszínről, hiszen csak egy bolond tenne erőfeszítéseket az éretlen gyümölcs után.

Az éles szemú meseíró az egyik - azóta már számtalan empirikus adattal alátámasztott - legalapvetőbb emberi jelenséget figurázta ki: az eredmények, helyzetek értékelésének utólagos torzítását. Hogy mennyire emberi ez a jelenség, azt talán nem is a szociálpszichológusok eredményei bizonyítják, hanem a kultúra maga. A Magyar Néprajzi Lexikon szócikke szerint a szőlő és a róka történetén alapuló szólásmondás egész Európában ismert. A mese megtalálható Phaedrus (i. sz. 1. sz.), Babrios (i. sz. 2. sz.), La Fontaine (17. sz.) fabulái között, Heltai Gáspár gyứjteményében, valamint Halm és Jacobs Aesopusában. (Ortutay 1977-1982). A róka és a szólő Aesopus több száz fabulájának egyik legismertebbjeként olyan szállóigét csempészett az európai kultúrkörbe, amely igen hatékony mémként terjedve jelenti mindenki számára érthetően mindig ugyanazt: az egyének az eredménytól függốn hajlamosak módosítani a dolgokról, folyamatokról, jellemvonásokról alkotott itéletüket.

Jelen tanulmányban az utólagos eredménytorzítás jelenségére épített kísérleti szituációban vizsgálom egy iskolai roma-integrációs program hatásvizsgálatát befolyásoló tényezôket, a szituációt és az érzelmeket.

\section{A hatásvizsgálat társadalmi háttere}

A romatelepeken kialakult szegregáció, a mélyszegénység, a természetes támogatórendszer gyengesége, a mindennapi kriminalizáció és viktimizáció együttesen határozza meg a gyermekek szocializációját, életesélyeit (Hüse, Szoboszlai és Fábián 2006). A romák az alacsony iskolai végzettségból, a munkanélküliségból és az etnikai diszkriminációból következôen, a rendszerváltást követô évtizedek leginkább marginalizált társadalmi csoportjává váltak. Mivel ebben a környezetben a fennálló társadalmi helyzet újratermelődésének nagyon nagy valószínûsége, törekedni kellett arra, hogy a mélyszegénység „öröklését” valami módon megelözzük. Nyíregyháza Huszár-telep nevú városrészében lezajlott spontán szegregáció következtében, a városrész általános iskolája „cigányiskolává” vált. Bár az iskola számos speciális programmal igyekezett tanulói továbbtanulási esélyeit, társadalmi integrációját elősegíteni - például a Soros Alapítvány „Lépésról-lépésre” programjával (Kerülő 2006), a telep közepén lévô intézmény továbbtanulási mutatói katasztrofálisak voltak, az erơfeszítések inkább csak a „programba való bevonás” rovatban értek el eredményeket, a kimeneti oldalon jobbára már hatástalanok maradtak (Hüse 2007). A Huszár-telep „utolsó megálló” lett, ahonnét már nincs tovább út. A negatív folyamatok visszafordítását haladéktalanul meg kellett kezdeni. A további lecsúszás megakadályozására 2007-ben az önkormányzat úgy döntött, hogy bezárja a telepi iskolát, és a tanulókat a város olyan iskoláiba integrálja be, ahol korábban igen alacsony volt a hátrányos helyzetú tanulók aránya (Kerülő 2008).

A nyíregyházi módszertani Gyermekjóléti Központ megalakulása óta egyik legfontosabb feladatának tekinti a hátrányos helyzetú gyermekek iskolai, illetve tár- 
sadalmi integrációjának elősegítését, különösen az etnikai okokból is szegregálódó, telepi roma gyerekek körében. A 2007-es önkormányzati döntés adott újabb lökést, egyúttal forrásokat a Gyermekjóléti Központ intenzívebb deszegregációs tevékenységéhez. A 2007 és 2010 közötti időszakban az intézmény szakemberei tíznél is több, különböző szemléletû és eszköztárú, integrációt elősegítő gyermekprogramot múködtettek, melyek közül több szempontból is kiemelkedik a nyírtelki Kedvesházpedagógiát (Bordács és Lázár 2002) valamint a resztoratív technikákat (Wachtel 2007) a befogadó iskolák osztálykörnyezetéhez adaptáló „Kedves iskolám” projekt.

A pedagógiai és resztoratív elemekre alapozott „Kedves iskolám” program három iskolában valósult meg a 2009-2010-es tanévben. A negyedikeseknek heti rendszerességgel szervezett, csoportmunkára és csoportélményre alapozott, játékos program - az „alkotó osztályközösség” - négy fóbb területre koncentrált: az együttmúködési, a szociális és a tanulási készségek, valamint a tanulási motiváció fejlesztésére. A szociális készségek fejlesztése a másság és a különböző kompetenciák kooperatív megélése során a kölcsönös tisztelet légkörében zajlott; szabályait a csoport maga alakította. Az együttmúködés, a tanulási motiváció és a tanulási készségek fejlesztése pedagógiai és tanulástechnikai eszközökkel kiegészített, klasszikus tréningalapokon zajlott - emellett természetesen nagy hangsúlyt kaptak a közös játékok, és az élmények együttes feldolgozása is (Tilmanné és Hüse 2010).

A városi integrációs projektek közül elsóként a „Kedves Iskolám” program végrehajtása során alkalmaztunk hatékonyságvizsgálatot. Többszempontú szociometriavizsgálattal, valamint tanári interjúk segítségével kívántuk kimutatni a korábbi szegregált oktatásból kikerülő gyermekeket befogadó osztályok társas mezejének változását, a befogadás mértékét. A Moreno (1934) által kidolgozott szociometria módszerét Mérei fejlesztette tovább, aki megalkotta a többszempontú szociogramot, azzal a céllal, hogy elôsegítse az oktatási intézményekben zajló közösségi élet megismerését. E módszer alapja a spontán kötődések, rokonszenven alapuló választások vizsgálata, melyben lényeges szempontok a különbözố feladatok megoszlása a csoport tagjai között, a funkciókon alapuló kontaktusok, illetve az alá-, fölérendeltségi viszonyok (Mérei 1996).

A szociometriai vizsgálatot a program kezdetén (szeptemberben), illetve a végén (május-június) vettük fel. Az egyik iskola kezdő és záró szociogramjának elemzésekor érdekes helyzet állt elô. Csupán a Mérei Ferenc által megadott elemzési szempontokra támaszkodva ezen iskola szociometriája egyértelmúen az osztályközösség szétesését, klikkesedését mutatta, amely az elemzésben részt vevô szakemberek számára elfogadhatatlan eredménynek túnt. Egyfelól azt az álláspontot képviselték, hogy a „Kedves iskolám” projekt, amely „módszertanilag olyan jó volt” nem eredményezhet olyan változást, mint amilyet a szociogramok mutatnak, másfelől a programban részt vevô pedagógusok beszámolói is egyértelmúen pozitívak voltak, a közösség épülésérôl, fejlődésérôl beszéltek. „Az osztály a szemünk láttára válik egyre inkább jól múködô csapattá" - állították. E tényezôk ismeretében az elemzók úgy értelmezték a kapott eredményt, hogy a „Kedves iskolám” program pozitív hozadékaként az osztály „nyitottabbá vált az integrációra, a befogadásra”. 
A szociogramok kreatív interpretációja természetesen sokkal inkább az értékelők elvárását tükrözte, semmint a többszempontú szociometria akkurátus értékelését.

Függetlenül attól, hogy a három iskolában felvett szociometriai tesztek végül milyen eredményt hoznak, az előbbiekben ismertetett disszonáns helyzet arra inspirált, hogy megvizsgáljam, mennyiben befolyásolják az elôzetes elvárások, illetve a külsó nyomás a hatásvizsgálatok eredményeinek laikus elemzóit, a pedagógusokat, szociális munkásokat.

A legtöbb integrációs program esetében igaz lehet, hogy a programra fordított erőforrások (pénz, idő, energia) hasznát igazolni kell, akár egy külsô tekintély-személynek (iskolaigazgató, polgármester), illetve tekintély-szervezetnek (önkormányzat, a projekt Irányító Hatósága). Az igazolási kényszer nyomása az eredmények rendkívül kreatív interpretációjára késztetheti a program szakembereit, akik legtöbbször személyesen függenek e tekintélyszemélyektől-szervezetektól, akár egzisztenciális értelemben is. Egy „sikeres” program esetén dicséretre, elismerésre, talán jutalomra is számíthatnak, míg ha „sikertelenségról”, „hatástalanságról” számolnak be, akkor valószínúsíthetô a büntetés - akár forrásmegvonás formájában is.

De nem csupán külsố nyomással számolhatunk. Az efféle projekteket megvalósító pedagógusok, illetve szociális szakemberek legtöbbször magasan motiváltak arra, hogy valóban elősegíthessék a hátrányos helyzetú tanulóik beilleszkedését, támogassák iskolai karrierjüket. Alkalmazott programjaiktól joggal várják, hogy eredményesek legyenek - minél tudományosabb eszköztárat vonultat fel egy program, annál inkább -, s eloozetes pozitív elvárásaik alakulhatnak ki a majdani eredmények kapcsán. Az elvárások természetesen negatívak is lehetnek, különösen, ha a beavatkozás célcsoportja előítéletességet vált ki a megvalósító szakemberekból.

\section{Az eredménytorzítások kutatásának fôbb megállapításai}

A vágyott dolog elérhetetlenségének disszonanciája irányította rá Brehm (1956) figyelmét a döntések utáni, visszamenóleges hatályú ítélkezésre, s ezzel egy új, igen jelentős fejezetett nyitott a kísérleti szociálpszichológia történetében. Brehm klasszikus vizsgálatában kimutatta, hogy a választás eredménye meghatározza a választás körülményeivel kapcsolatos utólagos értékítéleteket. Festinger (1957) alapvetô, a kognitív disszonanciáról és annak redukciójáról írott múvében foglaltakat továbbgondolva Aronson és Mills (1959) frappáns kísérlettel bizonyította, hogy az egyének hajlamosak felülértékelni azokat az eredményeket, amelyekért nagyobb áldozatot kellett hozniuk, mint azokat, amelyek eléréséért kevésbé kellett megszenvedniük. Ezzel egyidóben Festinger és Carlsmith (1959) kimutatta, hogy a névleges, szimbolikus külsố megerôsítés hatására jobban felértékelik az egyének az általuk végzett tevékenységet, illetve mélyebb, belsô meggyốzôdésé alakul ez a magas érték, ezzel szemben a magasabb, számottevô külsố megerôsítés - a tevékenység mások által 
magasabbra szabott „külső ára” - leértékeli a tevékenységet végző személy szemében annak „belső értékét”.

A személyközi kapcsolatok vizsgálatakor Heider (1958) úgy tekint a hétköznapi emberekre, mint „intuitív pszichológusokra”, akik a környezetükben lévő emberek viselkedését elemzik. Jones és Harris (1967) kísérletileg igazolta Heider feltételezését, mely szerint az egyének a viselkedés értelmezésében, értékelésében alábecsülik a szituációs tényezôk (környezeti tényezôk és kényszerítő erôk) fontosságát, miközben túlbecsülik a diszpozíciós tényezők (az értékelt személy képességei, motívumai) hatását. Az alapvetố attribúciós hiba - ahogy ezt a jelenséget később elnevezték jellegzetes eredménytorzításhoz vezet.

Hogyha a hétköznapi emberek természetesnek veszik, hogy ók meglehetôsen jó ,intuitív pszichológusok", akkor természetszerúleg biztosra mehetnek abban is, hogy ismerik, felismerik mások motivációit, attitűdjeit. De honnan nyerik ehhez az adatokat? E kérdés révén merült fel a hamis konszenzushatás (vagy egocentrikus attribúciós elfogultság) jelensége, azaz amikor az egyének azt feltételezik, hogy véleményük, viselkedésük „normális”, vagyis megegyezik az emberek többségének véleményével, viselkedésével. Ez egocentrikus eredménytorzításhoz vezet, hiszen az egyénnek valójában nincs konkrét információja arról, hogy az emberek többsége hogyan vélekedik a dolgokról, csupán arról, hogy ô maga milyen véleményt alkotott - azaz bármi is legyen az egyén véleménye, azt fogja átlagosnak, normálisnak, az emberek józan többsége által vallottnak tekinteni (Ross, Greene és House 1977).

Minthogy a jelen tanulmány alapját az etnikai kisebbség oktatási integrációjának érzékeny társadalmi kérdése adja, releváns eredményként citálhatjuk Baron és Hershey (1988) megállapítását is, mely szerint az egyének hajlamosak mások döntéseinek értékelésekor a döntés következményét, annak eredményét értékelni inkább. Azaz, bármilyen jó vagy rossz, kockázatos vagy óvatos volt a döntés, egyértelmúen pozitív elbírálásban lesz része, amennyiben az eredmények beváltják a reményeket, ám ha a folyamat eredményei elmaradnak az elvárttól, vagy netán kifejezetten katasztrofálisak lesznek, úgy az értékelook inkább figyelmen kívül hagyják a folyamatot befolyásoló környezeti tényezóket, és egyenesen a döntésre, illetve annak meghozójára terhelik ennek minden negatív, emocionális következményét. Az etnikai csoportok oktatási integrációjával szemben a többségi társadalom tagjainak egy része ellenérzésekkel viseltethet (Hüse 2011), sőt, minél erôteljesebb az előítéletesség, a szegregációra való törekvés az adott társadalomban, annál nagyobb tömegek éreznek annál mélyebb ellenérzéseket ezzel szemben (Szalai 2010). Miután az előítéletesség még manapság sem olyan tulajdonság, amelyre az egyén büszke lehet, ezért azt megpróbálja elfedni, racionálisnak túnó érvekkel körülbástyázni véleményét - melyben szinte mindig fellelhetô a hamis konszenzushatás s így például pozitív elvárásokat fogalmaz ugyan meg a roma gyerekek általános iskolai oktatása kapcsán, ám az általa elvárt eredmények irreálisak, illetve az elért eredményeket alulértékeli, ezáltal igazolni tudja elő́téletes, szegregáló attitúdjeit (Hüse 2008, Hüse 2011). 
Ugyancsak a jelen tanulmány társadalmi vonatkozásai miatt elgondolkodtató Allison és munkatársainak azon eredménye, mely szerint az eredménytorzításon alapuló következtetések hatása tartósan fennmarad, sőt, tovább erôsödik az idő elteltével, miközben azok a részletek, adatok, amelyekról az értékelók azt állították, hogy az eredmény értékelésében azokat figyelembe vették, teljességgel feledésbe merültek (Allison, Worth és King 1990). Ezzel tulajdonképpen az előítéletesség egyik forrásához, az előítéletes vélekedést tartósan fenntartó, megerősítő jelenséghez jutottunk el. Az eredménytorzított értelés és a sztereotípiák közötti kapcsolatra számos más tanulmány, vizsgálat is utal, ám ezeket - miután túlságosan messzire vezetnének - nem tárgyalom részletesebben.

Miközben a szociálpszichológia az eredménytorzítás mind több kicsiny részterületét, megjelenési formáját fedezi fel, a legújabb kutatásokban MRI képalkotó eljárás alkalmazásával az utólagos eredménytorzítás neurológiai alapjait kísérlik meg feltárni, illetve az evolúciós pszichológia érvrendszerével annak adaptivitását bizonyítani (Jarcho, Berkman és Lieberman 2010).

\section{Az érzelmek hatása a kognitív kiértékelésre}

A korai elméletek az érzelmek vizsgálatát igyekeztek kirekeszteni a kognitív folyamatok elemzéséból. Az 1930-as években az érzelmeket a gondolkodást és a tiszta logikát megzavaró reakcióknak tekintették, melyekkel az egyén a nehéz körülményekre reagál. El kellett telnie harminc évnek, hogy pszichológia nézôpontja megváltozzon, és az érzelmeket immár a környezeti körülményekre adott szisztematikus - tehát elemezhetố és értelmezhetô - válaszoknak tekintik, melyek az alkalmazkodást támogatják (Smith és Kirby 2004).

Elsőként Arnold (1960) jelenti ki, hogy az érzelmek szervezettek és az adaptációt szolgálják. Abból indul ki, hogy a különbözô érzelmek különbözô alkalmazkodási funkciókat szolgálnak. Az adott helyzet vonzó, vagy fenyegetô voltának megállapítására - más szóval kiértékelésére - „használja” az egyén az érzelmeket, mégpedig oly módon, hogy a jónak értékelt dolgokra megközelítéses, a rossznak értékelt dolgokra pedig elkerüléses választ adjon. Az érzelmek kutatóinak azt kell tehát vizsgálni, állítja Arnold, hogy milyen körülmények között, milyen mechanizmusok hívják elő az érzelmi választ. A kiértékelési elmélet késóbbi kutatóinak feladatát nehezítette, hogy az érzelmek nagyon is viszonylagosnak bizonyultak, és nem csak az adott szituáción alapultak (amely a vonzás-fenyegetés dichotóm skáláján helyezkedik el), hanem azon is, hogy ez a szituáció mit jelent az egyénnek, az egyén képességei, vágyai, szükségletei, kényszerei, stb. szempontjából.

Számos fantáziadús kísérlet bizonyítja az érzelmek befolyásoló erejét; ezek közül a döntéshozatalra, feladatmegoldásra való hatás vizsgálata érinti leginkább a jelen tanulmány témáját. Fredrickson szó-asszociációs feladattal, vagy csupán szavak felolvastatásával hangolta elő kísérleti alanyait, akiknek azután különbözô feladatokat kellett megoldaniuk. Az indukált pozitív emóciók hatására a gondolkodás felélénkült, kiterjesztette határait - azaz kreatívabbá vált (Fredrickson 1998; 2001), 
és ugyanilyen eredmények születtek a legkülönbözőbb csoportokban, az óvodásoktól az orvosokig (Isen 2000; Estrada, Isen és Young 1997).

A kiértékelési elmélet számos kutatója úgy vélte, hogy az egyének folyamatosan értékelik az óket körülvevô helyzetek jelentését. Azt mérik fel, hogy az alkalmazkodás - az egyén számára a sikeresség - szempontjából milyen viszonyban állnak akkor és ott a környezetükkel, a céljuk pedig az, hogy elkerüljék (vagy minimalizálják) a fenyegetô ártalmakat, illetve keressék (vagy maximalizálják) a potenciálisan kedvezô következményeket (pl. Smith és Lazarus 1990). A kiértékelési elmélet reprezentánsai kiemelik, hogy kiértékelés végbemehet automatikusan, tudatos figyelem nélkül is, bár a kiértékelés modellezése során olyan mechanizmusokat igyekeztek magyarázni, amellyel számos kritikusban azt a benyomást keltették, hogy a kiértékelés folyamata lassú, nehézkes, tudatos és akaratlagos, illetóleg alapvetően verbális gondolkodásra épül. E kritikákat ugyan rendre elutasították, de a kiértékelés strukturális modelljeinek keretrendszerében nem tudtak rá frappáns választ adni (Smith és Kirby 2004).

A kiértékelés strukturális modelljeire számos elmélet született, és valamennyit egymástól független vizsgálatok sorozata támasztja alá. Ezekben a vizsgálatokban releváns módon bizonyították, hogy különbözó érzelmek átélése megbízhatóan és szisztematikusan együtt jár a különbözô kiértékelésekkel, illetve azt, hogy az érzelmek és kiértékelések összefüggései megfelelnek a vizsgált modellek előrejelzéseinek. A kiértékelés különbözó strukturális modelljei közösek abban, hogy vizsgálják és magyarázzák, mennyire 1) fontos és 2) kívánatos az ingerhelyzet az egyén számára, hogy 3) képes-e, illetve 4) milyen mértékben megküzdeni a helyzettel, hogy 5) ki vagy mi okozta a helyzetet, illetve, hogy 6) ki vagy mi a felelós érte (azaz kire vagy mire irányuljanak a megküzdési erőfeszítések). A kutatók szerint a dimenziókban kapott kiértékelési eredmények vezetnek a különböző érzelmek átéléséhez (Smith és Kirby 2004).

Smith és Lazarus (1990) strukturális modellje szerint az egyének hét dimenzióban értékelik a helyzeteket

1. Motivációs relevancia - mennyire fontos a helyzet az egyén számára.

2. Motivációs kongruencia - a helyzet mennyire van összhangban az egyén aktuális céljaival.

3. Problémafókuszú megküzdési potenciál - az egyén mennyire képes maga alakítani a helyzetet úgy, hogy az kívánatosabb legyen, vagy kívánatos maradjon.

4. Érzelemfókuszú megküzdési potenciál - az egyén mennyire képes pszichológiailag alkalmazkodni a helyzethez, ha az nemkívánatos irányban alakul.

5. Önelszámoltathatóság - az egyén mennyire tartja saját magát felelősnek a helyzetért.

6. Mások elszámoltathatósága - az egyén mennyire tart másokat felelősnek a helyzetért. 
7. Jövóbeni kilátások - az egyén mit gondol arról, hogy a körülmények a jövôben kívánatosabbak (vagy nemkívánatosabbak) lesznek-e.

A kutatók számos eljárást dolgoztak ki arra, hogy kísérletileg ellenôrzött körülmények között kiváltsák az egyes érzelmeket, hangulati állapotokat. Bár az egyes technikák eltérô elônyökkel és hátrányokkal jellemezhetőek, a kísérletek azt bizonyítják, hogy a sokféle eljárással nagyon is hasonló hatások érhetőek el. A kísérletek során a hangulatok kiváltására a következô eljárásokat alkalmazták: szuggesztió (hipnózis), autoszuggesztió, szóbeli ön-utasítás (Velten-technika), hamis teljesítmény-visszajelzés, hangulatkiváltás szövegek segítségével, hangulatkiváltás filmek segítségével, jutalmak (Fiedler 2004).

Isen (1984), Clore, Schwarz és Conway (1994), Bless (2001), valamint Fiedler (2001) független vizsgálatai alapján kijelenthetjük, hogy az egyének különbözö érzelmek hatása alatt különbözó kognitív stílust alkalmazzanak. Negatív hangulatban az egyén hajlamosabb alaposan és érzékenyen figyelni az ingerek apró részleteire, míg pozitív hangulatban spontánabb, kreatívabb, heurisztikus megoldási módokat alkalmaz. Feltételezető, hogy a jó és rossz hangulatok evolúciós jelzésként szolgálnak: a negatív érzelem az ,állj és gondolkozz" cselekvés előtti jelentését hordozza, míg a pozitív érzelem arra inspirál, hogy „indulj, vágj bele”.

A helyzetek hangulatfüggó értékelésének kísérletei azonban számos ellentmondásos eredményre vezettek. Sok szerzó arról számol be, hogy bizonyos határfeltételek befolyásolják, korlátozzák a jelenséget, sôt, akár meg is fordíthatják azt. A hangulati megfelelést befolyásolja, hogy mennyire szokatlan a feladat, vagy az, hogy mekkora követelményeket támaszt az egyén képességeivel szemben, vagy mennyire komolyak a következmények. Ha teljesen hétköznapi, vagy túl könnyú a feladat, esetleg a következmények elhanyagolhatóak, akkor az érzelmek kevésbé befolyásolják az értékelést. A feladat ezen kívül kétféle módon határozható meg: nyitott, konstruktív módon - amikor az információk feldolgozása során új, még ismeretlen megoldásra kell találni -, valamint zárt, rekonstruktív módon, amikor egy elôzetesen meghatározott, vagy intuitíve nyilvánvaló megoldást meg kell védeni a zavaró információk beérkezésétől (Fiedler 2004).

A problémamegoldás konstruktív és rekonstruktív dimenziója, valamint az erôfeszítés mértékének dimenziója mentén Forgas (1995) négy alapvetô feldolgozó stratégiát jelölt ki Érzelmi befolyás modelljében (Affect Infusion Model, AIM). Eszerint az érzelmek serkentik a problémamegoldást a konstruktív feladatokban, ám nem befolyásolják a teljesítményt a rekonstruktív feladatok esetén. Komoly erőfeszítést igénylő, konstruktív feladat esetén a feldolgozás módja a lényegi feldolgozás, ugyanilyen nyílt helyzetben a könnyü feladatokra heurisztikus feldolgozás lesz a jellemző. Komoly erőfeszítést kívánó, rekonstruktív feladatok esetén motivált feldolgozásról beszélhetünk, míg a kicsi erőfeszítést kívánó, rekonstruktív feladatok esetén az emlékezeten alapuló közvetlen feldolgozásról. A négy, eltéró feldolgozási stratégia mentén az érzelmek eltérô hatással bírnak a kognitív stratégiákra.

Hasonló értelmezését kínál Allison, Mackie és Messick (1999) áttekintő tanulmánya. A szerzók az utólagos eredménytorzítás témájában keletkezett minden lénye- 
ges irodalmi forrást feldolgozva arra a következtetésre jutnak, hogy - többek között - az eredménytorzítás hátterében az egyének információfeldolgozási stratégiáinak különbözősége áll. Két alapvető stratégiát írtak le, a szisztematikus és a heurisztikus információfeldolgozásét. Míg az elóbbi szerint az egyének módszeresen sorra veszik a rendelkezésre álló adatokat, addig a heurisztikus stratégia során elötérbe kerülnek az intuitív eszközök, és a felületes összefüggésekre alapozott döntések. Az, hogy az egyének hajlamosak hinni abban, hogy „intuitív pszichológusként” jól boldogulnak mások viselkedésének elemzésével - ahogy korábban is tárgyaltam -, a heurisztikus információfeldolgozás nagyobb jelentôséget kap a hétköznapi életben. Allison és munkatársai arra is felhívják a figyelmet, hogy azok az egyének, akik erôsen inspiráltak arra, hogy az információkat alaposan feldolgozzák, vagy akik nem terheltek kongnitívan (pl. nem aggódnak, nem kell számtalan dologra figyelniük egyazon idôpontban), illetve akik fontos döntési, értékelési feladatot kapnak, azok kevésbé hajlamosak a heurisztikus stratégiát követni, mint a nem inspirált, kognitívan terhelt megfigyelók, vagy azok, akik nem tulajdonítanak nagy fontosságot az értékelési feladatnak.

\section{A kísérlet keretei}

Az integrációs programok hatásvizsgálatának eredményeit, illetve az eredmények értelmezését a fenti tényezók torzíthatják. E torzító hatás feltárására végeztem el a szociogram előhangolt értékelésére irányuló kísérletemet.

A megvizsgálni kívánt helyzetre vonatkozóan két hipotézist állítottam fel:

1. A fejlesztô programokkal szemben megfogalmazódó elvárás, külsố nyomás hat a szociometriai felmérés értékelésére; egy fejlesztô programnak fejlesztenie kell.

2. Az értékelook beállítódásán alapuló pozitív vagy negatív érzelmek befolyásolják a szociometriai felmérés eredményének utólagos értékelését; pozitív érzelmek hatása alatt kicsit pozitívabban, negatív érzelmek hatása alatt kicsit negatívabban értékelik az eredményeket.

A hipotézisek által felvetet kérdés megvizsgálására két független változót állítottam be a kísérletbe.

1. változó: a külsố nyomás keretrendszerének léte, illetve hiánya. [szituáció] Egy fejlesztô program esetében a program finanszírozója, illetve a program szakmai-szervezeti környezete felól érkezhet nyomás - várakozás a pozitív eredményre -, illetve a program szakemberei úgy érezhetik, hogy elszámolással tartoznak nekik arról, hogy a program valóban fejlesztett-e. A kísérleti elrendezés során a résztvevôk egy részének azt az információt adtuk, hogy a szociogramok egy fejlesztő program elején, illetve végén keletkeztek. A résztvevők egy másik része úgy tudta, hogy a két szociogram egy osztályfőnök 
kérésére készült a tanév elején, illetve végén, mert kíváncsi volt, hogy milyen folyamatok zajlanak az osztályában - azaz ez esetben nem beszéltünk fejlesztő programról, amelynek „elszámolhatóan és elvárhatóan” fejlesztenie kellene. Az elsố változó kontrollcsoportja ugyancsak ez utóbbi szituációval találkozott.

2. változó: az elóhangolás irányultsága. [hangolás] A pozitív, illetve negatív érzelmi előhangolással az előzetes beállítódás értékelésre gyakorolt hatását kívántam modellezni. Az elôhangolás során „szó-asszociációs feladatot” kellett megoldaniuk a kísérleti személyeknek, melyben 10 pozitív - illetve a másik csoportnak 10 negatív - érzelmi töltésú szó között kellett olyan rejtett asszociációt felfedezni, amely alapján két csoportba oszthatóak a szavak; illetve az így képzett két szócsoportnak valamiféle jellemző „címet” is kellett adniuk. A kontrollcsoport semleges érzelmi töltésú szavakkal végezte el ezt a feladatot.

A kísérletet a Debreceni Egyetem Tudományegyetemi Kara (pszichológus, szociológus), a Debreceni Egyetem OEC Egészségügyi Kara (ápolás és betegellátás), valamint a Nyíregyházi Fóiskola (szociálpedagógus) nappali, valamint kisebb létszámban levelező tagozatos hallgatóinak körében végeztem el. A kísérlet jellege miatt személyek közötti elrendezést alkalmaztam.

A kísérlet felvezetéseként minden csoportban rövid előadást tartottam a szociometria módszerérôl, annak céljáról, valamint a szociogram készítésének módjáról. Az elôadás fóként Moreno munkásságára irányult. Ezt követően megkértem a csoportot, segítsen nekem abban, hogy teszteljem a szociometria validitását, mivel a kritikák szerint a szociometria nem eléggé egzakt. Vizsgálatom most arra irányul, állítottam, hogy ha több ember értékeli ugyanazokat a szociogramokat, az értékelések között találhatunk-e hasonlóságot, és ha igen, mekkorát. Amennyiben az egymástól független értékelések eredményei között a hasonlóság nagy, akkor a szociometria valószínúleg megfelelố módszer a csoportok „belsố viszonyainak” mérésére. Eközben hangsúlyoztam, hogy lehetóleg a többiek befolyásolása és befolyásoló hatása nélkül végezzék el a feladatot. Ezzel arra apelláltam, hogy a hallgatók valóban segíteni akarnak abban, hogy a vizsgálatom jól sikerüljön, és motiváltabbá válnak arra, hogy betartsák a szabályokat. Várakozásom egyébként beigazolódott, minden csoportban rendkívüli módon ügyeltek a befolyásolás-mentes munkára.

Az előadás során kitértem arra is, hogy Moreno beállítottságát egyes kritikusai túlságosan „misztikusnak, messianisztikusnak” vélik, és olyannak tekintik, mint aki túlzott jelentôséget tulajdonít a spontaneitásnak (Mérei 1996:125-131) - ezt használtam fel arra, hogy megmagyarázzam, mi szükség van az előhangolásképpen beállított asszociációs feladatra. Azt állítottam, hogy ez az „asszociációs játék” Moreno „misztikus” módszereinek egyike, amellyel az ábrákon látható társas helyzetek jobb felismerésére készíthető fel az elme, ezzel - mint a csoportos értékelést alkalmazó kísérletvezetô - szeretnék visszatérni a gyökerekhez. Az előzetes tájékoztatásba a lehető legtöbb valós információt csempésztem, lényegében csak a manipulációkról hallgattam, illetve fedtem el dezinformációval, ám ezeket az információkat is 
megadtam a csoportokkal való utólagos megbeszélésen. Ezen a megbeszélésen igyekeztem információt nyerni arról is, hogy a manipuláció milyen mértékben hatotta át a kísérleti személyek érzelmeit, illetve gondolkodását (belehelyezték-e magukat a felkínált szituációba). Ezzel kapcsolatban megerôsítő szóbeli közléseket kaptam, ugyanakkor nem végeztem el a manipuláció egzaktabb ellenőrzését, azaz csupán erôs feltételezés, hogy a kísérleti csoportok tagjai zömében felvették a „fejlesztô program”, illetve a „pedagógus kíváncsisága” által sugallt beállítódást, valamint az asszociációs feladat valamilyen mértékben ténylegesen hatott a hangulatukra.

A kísérleti személyek informáltságában, illetve a kísérleti helyzet beállításában gondosan ügyeltem a tudományos kutatások - ezen belül is a szociálpszichológiai kutatások - etikai követelményeire, valamint arra, hogy a vizsgálatban érintett segítő hivatású, leendô szakembereket kellôen felkészítsem a vizsgálat tárgyának érzékeny társadalmi aspektusaira (vö. Drewry és Lawson 2010).

A kísérletben összesen 205 személy vett részt, a három képzóhelyen összesen négy csoportban. Mindegyik hallgatói csoport esetén véletlenszerúen soroltam be az egyes személyeket a kisérleti elrendezések alkotta csoportokba (1. táblázat).

\begin{tabular}{|l|r|r|r|}
\hline & Fejlesztố program & O.f. kíváncsisága & Összesen \\
\hline Pozitív elóhangolás & 50 & 45 & 95 \\
\hline Negatív elóhangolás & 49 & 44 & 93 \\
\hline Semleges elóhangolás & 0 & 17 & 17 \\
\hline Összesen & 99 & 106 & 205 \\
\hline
\end{tabular}

1. táblázat. Az egyes kísérleti elrendezésekben résztvevők létszáma.

A vizsgálathoz a bevezetóben is említett „Kedves Iskolám” program hatásvizsgálataként elkészítetett Mérei-féle több szempontú szociometriai felmérés két szociogramját használtam (1. és 2. ábra). Az eloohangolást követően e két ábrát megtekintve értékelést kellett adnia a hallgatóknak arról, hogy szerintük a csoportban lezajló változás pozitív, illetve negatív volt-e. Erre egy $129 \mathrm{~mm}$ hosszú egyenest használtam, melynek két végpontja a „teljesen negatív", illetve "teljesen pozitív" volt - az abszolút semleges középpont 64,5 mm-nél volt. A kísérleti személynek a kialakult véleményének, benyomásainak megfelelően egyetlen vonással kellett jelölnie az általa feltételezett változás minőségét. A kísérlet eredményeit az értékelő-egyenesen a „teljesen negatív” végponttól milliméterben mért értékkel adom meg. Az adatokat az $\mathrm{R}$ statisztikai programcsomag segítségével elemeztem (R Development Core Team, 2009).

\section{A kísérlet eredményei}

A teljes minta értékelésének átlaga 58,30, míg mediánja 53,00 volt, mindez elég nagy, 28,14-os szórás mellett. Úgy is fogalmazhatnánk, hogy a 205 kísérleti személy alapvetôen semleges, enyhén negatívba hajló értékelést adott az osztály társas há- 


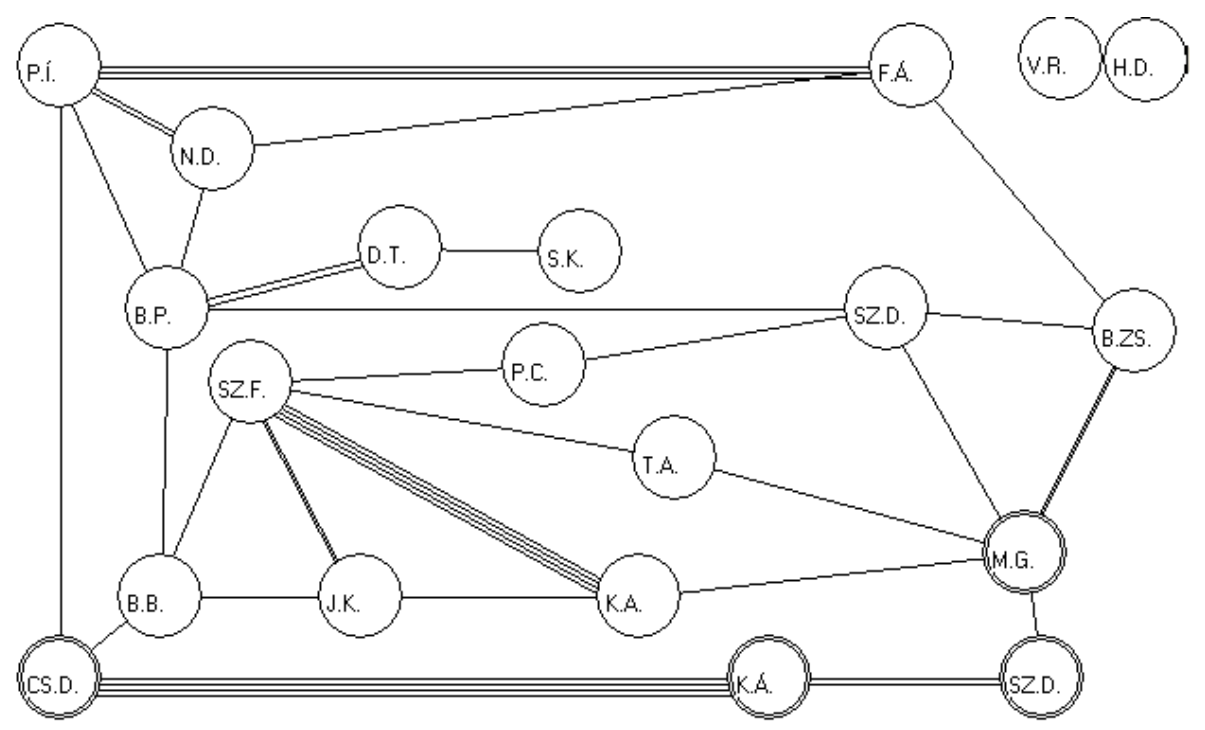

1. ábra. Az első szociogram.

lózatának változását illetôen. Az értékelést, mint a vizsgálódásom tárgyát képezô függô változót normalitásvizsgálatnak vetettem alá: az egymintás KolmogorovSzmirnov próba kimutatta, hogy a mintám nem normál eloszlású $(\mathrm{p}=0,03832)$, ennek megfelelóen kellett a statisztikai eljárásokat alkalmaznom. A nem normál eloszlás következményeként a középértékek közül az átlag helyett a mediánra alapozom az elemzésem.

A szituációfüggő helyzetben a „fejlesztô program” és az „osztályfoonök egyszerû kíváncsisága" adta a független változó két értékét. A fejlesztő program eredményét értékelők egy kicsit pozitívabban látták a két mérés közötti változást, az értékelésük mediánja 59,00 volt (N:99). Azok, akik nem számoltak semmiféle fejlesztô program hatásával, negatívabban értékelték a folyamatot, a minta mediánja 49,00 volt (N:106). Mindkét esetben közel 28-as szórást mutatott a minta. Ezzel, ha csupán kicsiny mértékben is, de igazolódni látszik a hipotézis, mely szerint a fejlesztô programmal kapcsolatosan megjelenik az elvárás annak pozitív fejlesztô hatását illetôen.

A másik manipuláció, az érzelmi elóhangolás is különbségeket teremtett a két csoport között. A pozitívan előhangoltak az átlaghoz közel, csupán enyhén negatívan értékelték a két szociogram felvétele között lezajlott folyamatokat - az egyértelmúen negatív képet mutató második szociogram ellenére is a kísérleti csoport értékelésének mediánja 55,00 volt (N:95). A negatívan elóhangoltak egy kicsit negatívabban látták a folyamatot, mediánjuk 51,00 (N:93). A különbség látszólag ez esetben is igazolja a hipotézist, mely szerint az érzelmek irányultságával egyenes 


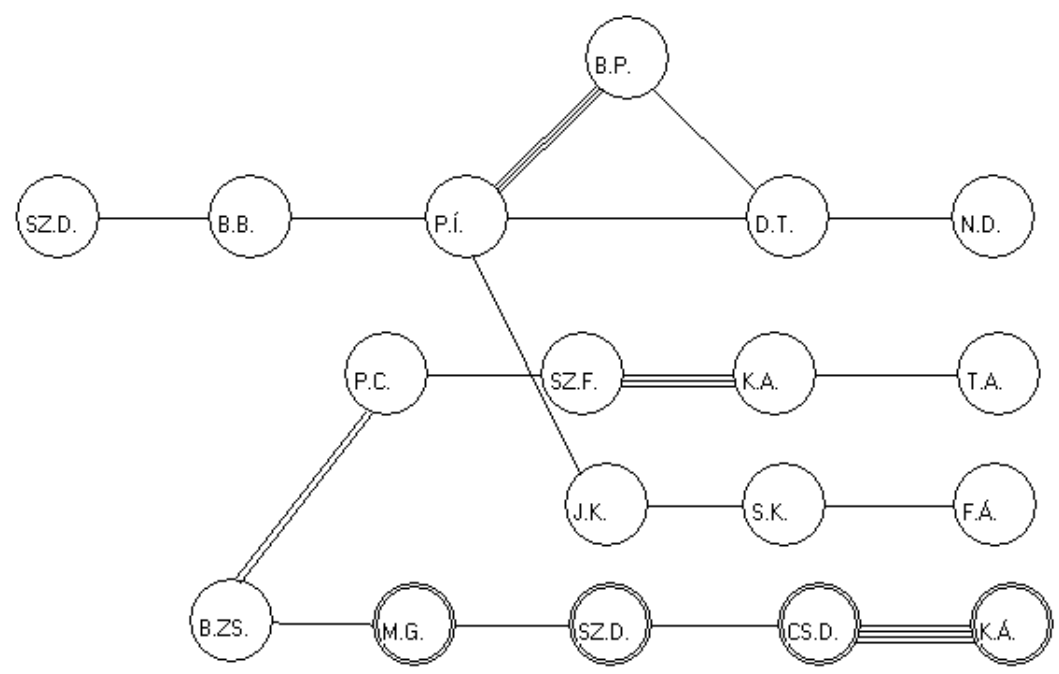

2. ábra. A második szociogram.

arányban mozdul el az értékelés irányultsága. Érdekes módon a semlegesen elôhangolt kontrollcsoport produkálta a leginkább negatív értékelést, mediánjuk 48,00 volt (N:17), így ez gyengíti a hipotézis igazolását.

A két független változó a kísérleti elrendezésnek köszönhetően természetesen nem külön-külön, hanem együttesen hatott, hathatott a kísérleti személyek értékelésére. A két független változót egyetlen, öt értékkel bíró változóba vonva meglepó eredményt kaptunk. A „kíváncsi osztályfönök” által készíttetett szociogramokat értékelók a fentieknek megfelelően viselkedtek az érzelmi manipulálás hatására: a pozitívan elóhangoltak kissé pozitívabbnak (medián $=55,00$ ) látták a változást, mint a negatívan előhangoltak (medián $=45,50)$. A kontroll csoport ebból a szempontból a „helyére került” a maga közepes mediánjával $(48,00)$.

Ezzel szemben a „fejlesztô program” hatását értékelők esetében az érzelmi előhangolás pont fordított hatást váltott ki: a pozitívan elóhangoltak értékelték negatívabban a folyamatot (medián $=57,00$ ), és a negatívan elóhangoltak pozitívabban (medián $=59,00)$. Ezt az érdekes jelenséget boxplot diagramon ábrázolva jól láthatjuk, hogy nem csupán a medián esetében, de alapvetően a többi quartilisnél is megfigyelhetjük (3. ábra).

A két változó együttes hatása megfelel a Fiedler (2004) által leírt határfeltételek esetén tapasztaltaknak, mely szerint bizonyos határfeltételek akár meg is fordíthatják az érzelmek értékelésre gyakorolt hatását. Úgy tûnik, a hatásvizsgálat eredményének értékelése szempontjából a szituáció ilyen határfeltételként viselke- 


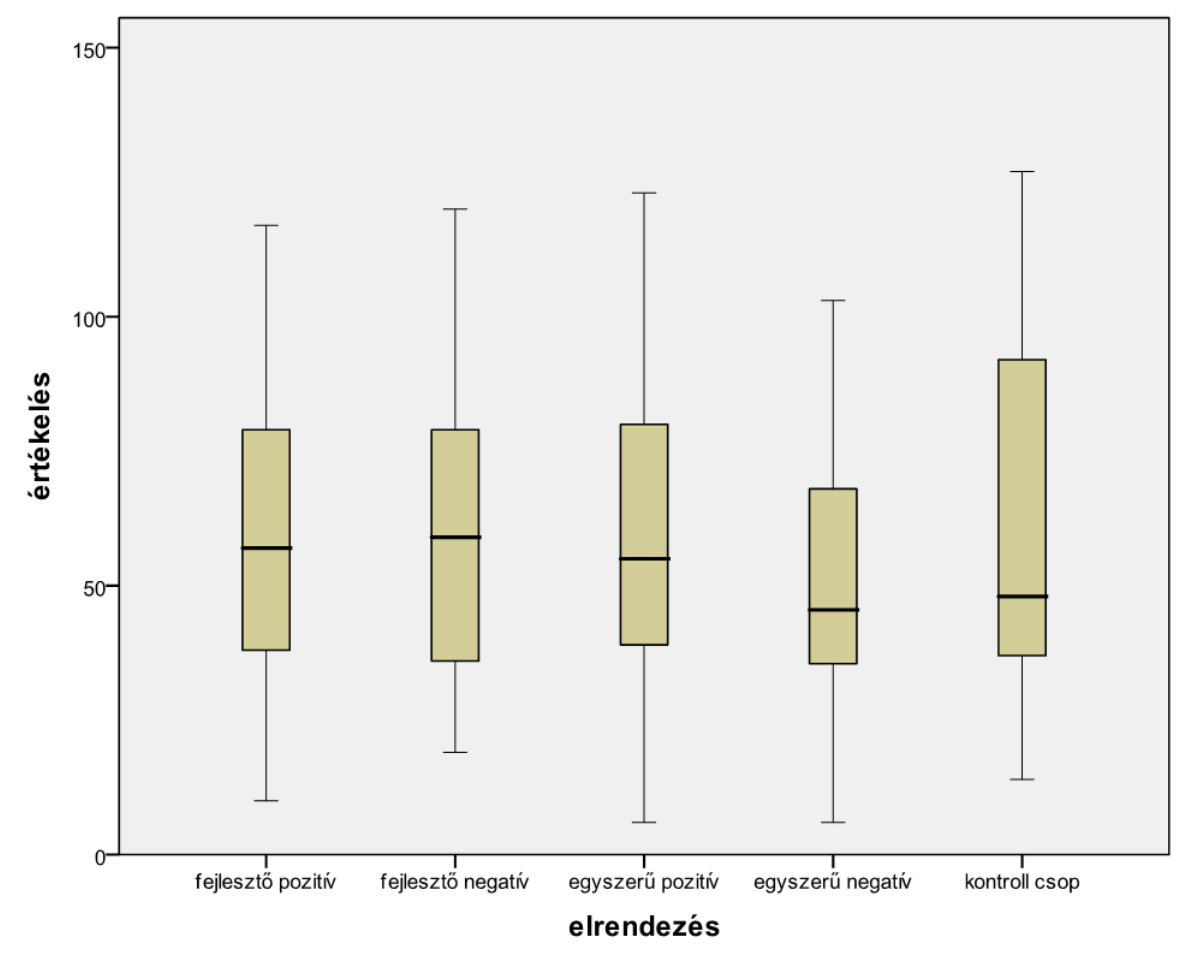

3. ábra. Az öt kísérleti elrendezésben született értékelések quartilisei.

dik, azaz, amennyiben egy nagyobb súlyú, több elvárással megterhelt szituációt állítunk vizsgálódásunk középpontjába (,fejlesztő program”), akkor az érzelmi irányultság hatása ellentétes lesz.

Amennyiben a kísérlet eredményét Allison és munkatársai (1999) által összefoglalt problémamegoldó modellek fényében vizsgáljuk, az értelmezésünk hasonló eredményekre vezet. Eszerint az értékelést végző egyének a „fejlesztő program” eredményének elemzésekor félreteszik a heurisztikus problémamegoldó modellt, amely egyébként kitűnően alkalmas a jóval kisebb jelentôségư, elvárásoktól nem terhelt szituáció értékelésére („osztályfőnök egyszerú kíváncsisága”), és szisztematikus módon megpróbálják elemezni a rendelkezésre álló - ez esetben grafikai - adatokat. A szisztematikus elemzés során az a vizsgálati személy, akit negatív érzelmekre hangoltuk elő, negatív érzelmeinek ,állj meg, gondolkozz” üzenete hatására több érvet gyưjthet amellett, hogy egy fejlesztő programnak fejlesztenie kell, mint a pozitívan elóhangoltak. Ezzel szemben a heurisztikus adatfeldolgozók jobban átadják magukat érzelmeik felszínes hatásának, és a pozitívan előhangoltak pozitívabb fényben érzékelik az egyébként sem túl jelentôségteljes szituációt. 
Az egyes változók manipulálása tehát az elvárásoknak megfelelően befolyásolta a kísérletben résztvevôk értékelését, noha ezen elvárások nem mindegyike fogalmazódott meg a vizsgálati hipotézisekben, hiszen azok nem tértek ki a határfeltételek kérdésre. Annak az egzakt megállapítására, hogy a szituáció, illetve az elóhangolás manipulációja milyen mértékben hatott a szociogram-pár utólagos eredményértékelésére, a nem normál eloszlású változók esetében releváns nemparaméteres eljárást alkalmaztam. Az öt kísérleti elrendezés mediánjainak különbözőségét KruskalWallis próbával vizsgáltam meg, mely szerint a vizsgált csoportok mediánjai között nincs szignifikáns különbözőség (Kruskal-Wallis chi-squared=3,1334, df=4, pvalue $=0,5358)$. Statisztikai érvényességgel tehát nem tudtam igazolni, hogy az egyes csoportok közötti, a szakirodalom alapján jól magyarázható, de enyhe eltérés megerősítené a kísérleti hipotéziseket.

\section{Összegzés}

A mélyülő társadalmi különbségek orvoslásának egyik lehetséges útja a hátrányos helyzetú, szegregálódó, vagy már szegregálódott, mélyszegénységben élő csoportok oktatásán át vezet. Ezen belül is kifejezetten fontos ezen csoportok gyermekeinek megfelelố oktatása - és ahogy a hangsúly a megfelelőségen van, úgy a legtöbb vitát kiváltó aspektus is ugyanez: az iskolai színtéren alkalmazható mely modellek, mely eszközök és technikák a leginkább megfelelőek a társadalmi hátrányok leküzdésében ... és kinek felelnek meg leginkább. A kérdés - végletesen leegyszerúsítve - manapság Magyarországon így hangzik: a szegregált, vagy az integrált oktatás modellje követendô inkább a roma gyermekek iskolai oktatásában? A kérdés mélyén azonban nem csupán tudományos, illetve oktatásszervezési, oktatásirányítási kíváncsiság rejlik, hanem az egyes társadalmi csoportok javakért való versengése, az előítéletesség, a xenofóbia is (Szalai 2010). Ebben a valóban fontos, többrétú kérdésben nem hagyatkozhatunk pusztán az oktatásszociológusok adatgyújtésére, sem a szociálpolitika elméleteire, a szociális munka tapasztalataira, hanem fel kell használnunk az egyes helyi programokban manifesztálódó eredményeket is, melyhez ezen programok hatásvizsgálatán keresztül jutunk.

A nyíregyházi deszegregációs program részeként megvalósuló „Kedves iskolám” projektben résztvevô tanulók Mérei (1996) többszempontú szociometriáján alapuló hatásvizsgálathoz szolgáltattak adatokat. Az egyik iskolában azonban az így kapott kép nem felelt meg a programban részt vevő szakemberek tapasztalatainak; míg a szociometria negatív folyamatot mutatott, szétesô csoportról tanúskodott, addig a szakemberek személyes tapasztalatai egyértelmúen pozitívak voltak, és az osztály összekovácsolódásáról beszéltek. A disszonáns helyzetet a szakemberek utólagos eredménytorzítással magyarázták, meglehetôs kreativitással látva bele a pozitív hatást az egyébként negatív mérési eredménybe.

Miután az iskolai integrációs programok eredményei nem csupán a tudomány és az oktatáspolitika érdeklôdésére tarthatnak számot, de ki kell állniuk a sztereotipizált közvélekedés kritikus nyomását is, rendkívül fontos kérdéssé válik az 
eredményeket prezentáló hatásvizsgálatok validitása. A „Kedves iskolám” hatásának kreatív interpretálása rámutatott, hogy ezek az eredmények számos tényezó révén torzulhatnak, illetve, hogy a hatásvizsgálatok esetében „beépített hibalehetôségként" kell számolnunk az eredménytorzítás jelenségével (Allison, Mackie és Messick 1999). Ezért kísérletem arra irányult, hogy megvizsgáljam, milyen módon hat az egyértelmûen negatív csoportfolyamatokat sugalló szociogram-pár értékelésére az elôzetesen indukált érzelmek irányultsága, illetőleg a szituációtól függő elvárások, vélt külső nyomás megléte.

Nem szignifikáns eredményértékelési különbséget tapasztaltam mind az érzelmek, mind a szituációk manipulását követően. További eredmény mutatkozott a két változó együttes elemzésekor, mely során kiderült, hogy a szituáció határfeltételként múködve (Fiedler 2004) ellenkezőjére fordította a negatív érzelmek hatását a kétféle kísérleti elrendezésben. A „fejlesztô programot” értékelők közül a negatívan elôhangoltak minimálisan pozitívabbnak látták a változást, míg az „egyszerú osztályfelmérést" elemzók közül pont fordítva, negatívabbnak értékelték a folyamatot - ez egybevág Forgas kísérleteinek eredményével, mely szerint a negatív hangulat az interperszonális feladatok hatékonyságát serkenti (2007). A semleges érzelmekre hangolt kontrollcsoport is az „egyszerú osztályfelmérés” szituációjában vett részt, és némileg negatívabban látta a folyamatokat, mint pozitívan eloohangoltak, de pozitívabban, mint a negatívan elóhangoltak.

Miután ezeket az eredményeket „laboratóriumi” kísérlet keretei között kaptam, alapos indokkal feltételezem, hogy amennyiben a hatásvizsgálatokat az iskolai integrációs programok érintett, motivált és külső kényszerek közt tevékenykedô szakemberei végzik el - márpedig ez meglehetősen életszerû -, akkor mind az érzelmek, mind a szituáció sokkal erôsebben fejti ki hatását az értékelésre, felerôsítve az utólagos eredménytorzítás jelentôségét. E feltételezésem bizonyítására további kísérlet szükséges, melynek kereteit kitágítva be kellene építenem az egész integrációs programot, annak hatásvizsgálatát, és természetesen a hatásvizsgálat eredményének értékelését. Ez azonban - lévén, ezen integrációs programok hátrányos és nemhátrányos helyzetú gyermekek egész tanévét, sôt, talán nem túlzás azt állítani, hogy bizonyos mértékben a jövôjét is érintik - komoly etikai dilemmákat (Drewry és Lawson 2010) vet fel a kísérlet megvalósításával kapcsolatban. Úgy vélem ezért, a célnak leginkább a tárgyalás-pszichológia diádikus kísérleti helyzeteinek reprodukálása felelne meg leginkább, független (az integrációs programokban nem érintett) kísérleti személyek bevonásával. Ezzel választ találhatunk az etikai megfontolásokra, ráadásul várható, hogy a diádikus helyzetben a papír-ceruza teszt során kapott nem szignifikáns eredmények - más hasonló kísérleti szériákhoz hasonlóan - szignifikáns erôvel mutatkozhatnak meg (v.ö.: Okhuysen, Galinsky és Uptigrove 2003). 


\section{Irodalomjegyzék}

1. Allison, S. T., Mackie, D. M., Messick, D. M. (1999): Eredménytorzítások a szociális percepcióban: a diszpozicionális következtetések implikációi, attitûdváltozás, sztereotipizálás és társas viselkedés. In: Hunyady Gy., Hamilton, D. L., Anh, N. L. L. [szerk]: A csoportok percepciója. Akadémiai Kiadó, Budapest. 130-165.

2. Allison, S. T., Worth, L. T., King, M. W. C. (1990): Group decisions as social inference heuristic. Journal of Personality and Social Psychology 58: 801-811.

3. Arnold, M. B. (1960): Emotion and personality. Columbia Univ. Press, New York.

4. Aronson, E., Mills, J. (1959): The effect of severity of initiation on liking for a group. Journal of Abnormal and Social Psychology 58: 177-181.

5. Baron, J., \& Hershey, J. C. (1988). Outcome bias in decision evaluation. Journal of Personality and Social Psychology 54: 569-579.

6. Bless, H. (2001): Mood and the use of general knowledge structures. In: Martin, L. L., Clore, G. L. [szerk.]: Theories of mood and cognition: A user's guidebook. Erlbaum, Mahwah NJ. 9-26.

7. Bordács Margit, Lázár Péter (2002): Kedveskönyv. Módszerek, gyakorlatok a Kedvesház-pedagógia tapasztalatai alapján roma és/vagy hátrányos helyzetú gyermekeket nevelő pedagógusok számára. Gyermekekért SOS '90 Alapítvány - Dinasztia Tankönyvkiadó, Budapest.

8. Brehm, J. W. (1956): Post-decision changes in desirability of alternatives. Journal of Abnormal and Social Psychology 52: 384-389.

9. Clore, G. L., Schwarz, N., Conway, M. (1994): Cognitive causes and consequences of emotion. In: Wyer, R. S., Srull, T. K. [Szerk.]: Handbook of social cognition (2). Erlbaum, Hillsdale NJ. 323-418.

10. Drewry, S., Lawson, T. R. (2010): Operationalizing codes of international research ethics: The role of social work. Acta Medicinae et Sociologica Vol. 1. No. 1: $9-22$.

11. Estrada, C. A., Isen, A. M., Young, M. J. (1997): Positive affect facilitates integration of information and decreases anchoring in reasoning among physicians. Organisational Behaviour and Human Decision Processes 72: 117-135.

12. Festinger, L. (1957): A theory of cognitive dissonance. Stanford Univ. Press, Stanford.

13. Festinger, L., Carlsmith, J. M. (1959): Cognitive consequences of forced compilance. Journal of Abnormal and Social Psychology 58: 203-210.

14. Fiedler, K. (2004): Érzelmi hatások a társas információfeldolgozásra. In: Forgas, J. P. [szerk.]: Az érzelmek pszichológiája. Kariosz Kiadó, Budapest. 163-183. 15. Fiedler, K. (2001): Affective states trigger processes of assimilation and accomodation. In: Martin, L. L., Clore, G. L. [szerk.]: Theories of mood and cognition: A user's guidebook. Erlbaum, Mahwah NJ. 85-98.

16. Forgas, J. P. (2007). When sad is better than happy: Negative affect can improve the quality and effectiveness of persuasive messages and social influence 
strategies. Journal of Experimental Social Psychology 43: 513-528.

17. Forgas, J. P. (1995): Mood and judgement: The Affect Infusion Model (AIM). Psychological Bulletin 117: 39-66.

18. Fredrickson, B. (2001): The role of positive emotions in Positive Psychology: The boarden-and-build theory of positive emotions. American Psychologyst 56: 218-226.

19. Fredrickson, B. (1998): What good are positive emotions? Review of General Psychology 2: 300-319.

20. Heider, F. (1958): The psychology of interpersonal relations. Wiley, New York.

21. Hüse Lajos (2011): Kettôs mérce az iskola szerepének megítélésében - egy kirekesztés-kutatás margójára. Iskolakultúra 2011/1: 88-98.

22. Hüse Lajos (2008): A kirekesztés diskurzusa. Kapocs VII/5: 2-23.

23. Hüse Lajos (2007): Szűz Mária zsebkendőjének keleti csücskében. Esély 2007/5: 126-130.

24. Hüse Lajos, Szoboszlai Katalin, Fábián Gergely (2006): A semmi ágán ... Hátrányos helyzetû csoportok sérelmére elkövetett cselekmények kutatása. Periféria Egyesület, Nyíregyháza.

25. Isen, A. M. (2000): Positive affect and decision making. In: Lewis, M., Haviland-Jones, M. [szerk.]: Handbook of emotions (2). Guilford Press, New York. 417-435.

26. Isen, A. M. (1984): Toward understanding the role of affect in cognition. In: Wyer, R. S., Srull, T. K. [Szerk.]: Handbook of social cognition (3). Erlbaum, Hillsdale NJ. 179-236.

27. Jarcho, J. M., Berkman, E. T., Lieberman, M. D. (2010): The neural basis of rationalization: cognitive dissonance reduction during decision making. Social Cognitive and Affective Neuroscience (elektronikus folyóirat, scan.oxfordjournals.org) July 9, 2010: 1-8.

28. Jones, E. E., Harris, V. A. (1967): The attribution of attitudes. Journal of Experimental Social Psychology 3: 1-24.

29. Kerülő Judit (2008): Az integráció és a szegregáció kérdése egy iskolabezárás kapcsán. Új Pedagógiai Szemle 2008/2: 12-29.

30. Kerülő Judit (2006): Kitörési esélyek egy nyomortelepról. In: Fónai M., Pénzes M. és Vitál A. [szerk.]: Etnikai szegénység, etnikai egészségi állapot? - A cigány népesség élethelyzete és kitörési lehetőségei Északkelet-magyarországon. Krúdy Könyvkiadó - Szocio East Egyesület, Nyíregyháza. 195-217.

31. Mérei Ferenc (1996): Közösségek rejtett hálózata. Osiris, Budapest.

32. Moreno, J. L. (1934): Who shall survive? Foundations of sociometry, group psychotherapy and sociodrama. Beacon House, New York.

33. Okhuysen, G. A., Galinsky, A. D., Uptigrove, T. A. (2003): Saving the worst for last: The effect of time horizon on the efficiency of negotiating benefits and burdens. Organizational Behavior and Human Decision Processes 91: 269-279.

34. Ortutay Gy. [szerk.] (1977-1982): Magyar néprajzi lexikon. Akadémiai Könyv- 
kiadó, Budapest.

35. R Development Core Team (2009). R: A language and environment for statistical computing. R Foundation for Statistical Computing, Vienna, Austria. http:www.R-project.org

36. Ross, L., Greene, D., House, P. (1977): The false consensus phenomenon: An attributional bias in self-perception and social perception processes. Journal of Experimental Social Psychology 13: 279-301.

37. Smith, C. A., Kirby, L. D. (2004): Az érzelem és a kognitív kiértékelés folyamatai. In: Forgas, J. P. [szerk.]: Az érzelmek pszichológiája. Kariosz Kiadó, Budapest. 79-95.

38. Smith, C. A., Lazarus, R. S. (1990): Emotion and adaptation. In: Pervin, L. A. [szerk.]: Handbook of personality: Theory and research. Guilford, New York. 609-637.

39. Szalai Júlia (2010): A szabadságtalanság bôvülő körei. Az iskolai szegregáció társadalmi ,értelméről”. Esély 2010/3: 3-22.

40. Tilmanné T. Erika, Hüse Lajos (2010): Roma tanulók iskolai integrációját támogató program hatásvizsgálata. Háló XVI/11-12: 23-27.

41. Wachtel, T. (2007): Real Justice. Hogyan forradalmasíthatjuk a normasértéshez való viszonyulásunkat? The Piper's, Pipersville. 
Hüse Lajos fôiskolai adjunktus

Debreceni Egyetem, Egészségügyi Kar, Nyíregyháza, 4400, Sóstói út 2-4. 